УДК 343.85:[343.226:316.36](076)

DOI https://doi.org/10.32849/2663-5313/2020.6.38

\title{
Алла Блага,
}

докт. юрид. наук, дочент,

завідувач кафедри цивільного та кримінального права і процесу

Чорноморського національного університету імені Петра Могили

\section{Олена Кочемировсъка,}

канд. психол. наук, дочент,

старший координатор з питань гуманітарного реагування на Сході Украӥни

Фонду Організаиій Об’єднаних Націй у галузі народонаселення в Украӥні

\section{ДОПОМОГА Й ЗАХИСТ ПОСТРАЖДАЛИХ ВІД ДОМАШНЬОГО НАСИЛЬСТВА: СУЧАСНИЙ СТАН ТА ОСНОВНІ ПРОБЛЕМИ ПРАВОВОГО РЕГУЛЮВАННЯ}

Стаття присвячена аналізу змісту, сучасного стану надання допомоги та захисту постраждалим від домашнього насильства особам як окремого напряму діяльності суб'єктів у сфері запобігання та протидії иьому явищу, а також проблем, які виникають із цього приводу. Встановлено, що захист та підтримка постраждалих осіб здійснюються за допомогою своєчасного реагування, припинення акту насильства і захисту постраждалих з боку поліиії, а також підтримки постраждалих та надання їм необхідної медччної, психологічної, сочіальної, правової допомоги та послуг з боку неурядових організачій, бюро та центрів правової допомоги, органів прокуратури, судових органів (доступ до правосуддя), загальних та спещіалізованих служб підтримки постраждалих осіб, таких як притулки, телефонні «гарячі лінї» та інші. Наголошено на необхідності прояву фахівиями поваги і чуйності до постраждалих і надання останнім можливості самостійно приймати обгрунтовані рішення, які найкраще відображають їхні інтереси. Проаналізована спещифіка надання постраждалим особам інформаиї про їхні права та можливості реалізаиії таких прав та вказано на наявний дефіиит друкованих інформачійних матеріалів з контактами служб, до яких особа може звернутись у своєму населеному пункті. Визначені проблемні моменти щодо забезпечення доступу до загальних та спечіалізованих служб підтримки постраждалих осіб для отримання соціальних послуг, медичної, соиіальної, психологічної допомоги. Встановлений сучасний стан та перспективи надання таким особам послуги тимчасового притулку для безпечного розміщення, та підкреслена необхідність розширення мережі спеиіалізованих кризових иентрів. Проаналізована ситуачіл із забезпечення постраждалим особам доступу до правосуддя та інших механізмів юридичного захисту у тому числі шляхом надання безоплатної правової допомоги. Розглянута діяльність Мінсоиполітики України та Уряду країни стосовно утворення иілодобового безоплатного кол-иентру з питань запобігання та протидії домашньому насильству, насильству за ознакою статі та насильству стосовно дітей.

Ключові слова: домашнє насильство, постраждалі, допомога, захист, запобігання.

Постановка проблеми. Щорічно в Україні реєструється більше ста тисяч заяв, повідомлень про вчинені правопорушення та інші події, пов'язані з домашнім насильством. Так, за 2019 рік до органів Національної поліції надійшло 141814 таких звернень. I це не просто число - за кожною такою заявою стоять конкретні постраждалі жінки, чоловіки, діти, які потребують захисту та підтримки. Особливу роль в удосконаленні українського законодавства у сфері запобігання та протидії домашньому насильству відіграє заснована на найкращому досвіді Конвенція Ради Європи про запобігання насильству стосовно жінок і домашньому насильству та боротьбу із цими явищами (або Стамбульська конвенція) [1]. 3 урахуванням їі положень прийнятий у 2017 році Закон України «Про запобігання та протидію домашньому насильству» (далі - Закон про домашне насильство) закріпив на законодавчому рівні напрям надання допомоги та захисту постраждалим особам [2].

Аналіз останніх досліджень і публікацій. Вагомий внесок у закладення основи нової політики у сфері запобігання та протидії домашньому насильству та насильству за ознакою статі, дослідження різних аспек- 
тів запобігання та протидії насильству, визначення ефективності форм та методів запобіжного впливу зробили такі науковці та суспільні діячі, як В. Голина, О. Джужа, Т. Журавель, О. Ковальова, К. Левченко В. Туляков, Н. Федорович, М. Хавронюк, Г. Христова та багато інших. Однак, незважаючи на те що з часу прийняття Закону України «Про запобігання та протидію домашньому насильству» минуло вже більше двох років, практика його застосування засвідчила потребу у теоретичному і практичному опрацюванні багатьох положень цього закону.

Вітчизняне законодавство закріпило закладений у Стамбульській конвенції підхід, орієнтований на потреби постраждалої особи. Це, у свою чергу, потребує опрацювання підходів, яких повинні дотримуватися суб'єкти, що вживають заходи у сфері запобігання та протидії домашньому насильству, у наданні допомоги та захисту постраждалим особам

Мета статті полягає у з'ясуванні змісту, сучасного стану надання допомоги та захисту постраждалим від домашнього насильства особам та проблем, пов'язаних ॥ із цим явищем.

Виклад основного матеріалу. Для того, щоб постраждалі від домашнього насильства особи отримали максимально можливу допомогу, акцент усіх застосовуваних заходів повинен бути зроблений на їхніх правах, потребах та безпеці. Це означає, що, коли щодо постраждалих існує ризик продовження або повторного вчинення насильства, на першому місці повинні стояти ї захист і підтримка.

Захист та підтримка постраждалих осіб здійснюються за допомогою своєчасного реагування, припинення акту насильства і захисту постраждалих з боку поліції, а також підтримки постраждалих та надання їм необхідних медичної, психологічної, соціальної, правової допомоги та послуг з боку неурядових організацій, бюро та центрів правової допомоги, органів прокуратури, судових органів (доступ до правосуддя), загальних та спеціалізованих служб підтримки постраждалих осіб, таких як притулки, телефонні «гарячі лінії» та інші.

Зміст цього напряму полягає у вжитті необхідних заходів, спрямованих на: уникнення повторної віктимізації, надання самостійності та економічної незалежності постраждалим від насильства, урахування особливих потреб уразливих осіб, у тому числі постраждалих дітей, отримання відповідної та своєчасної інформації про доступні служби підтримки та правові заходи мовою, яку розуміють постраждалі особи.
Законодавче закріплення цього напряму діяльності у сфері запобігання та протидії домашньому насильству (ст. 20-23 Закону про домашнє насильство) має надзвичайно велике значення, адже таким чином постраждалі можуть отримати досить широке коло можливостей. Так, усі задіяні фахівці повинні розуміти реалії та проблеми постраждалих від домашнього насильства (особливо 3 урахуванням їхнього можливого уразливого стану внаслідок вікових особливостей, стану здоров'я, статі, релігійних переконань, етнічного походження тощо) і сприяти у їх прагненні відновити своє життя (ч. 3 ст. 20 зазначеного Закону); постраждалі можуть отримати допомогу за місцем звернення, а не за місцем реєстрації (ч. 4 цієї ж статті); надання допомоги чи послуг наразі не залежить від готовності постраждалої особи висунути обвинувачення або свідчити проти свого кривдника (ч. 5 цієї ж норми). Крім того враховано, що у багатьох випадках насильства батьки дитини або опікуни недієздатних осіб і є ї кривдниками. Тож питання надання допомоги таким постраждалим вирішують органи опіки та піклування (ч. 6 і 7 ст. 20 вказаного Закону) [2].

Дослідження сучасного стану надання допомоги та захисту постраждалим від домашнього насильства особам та встановлення наявних пов'язаних із цим проблем нами було здійснене за допомогою методу експертного опитування. Експертами виступили 116 фахівців Київської, Запорізької, Полтавської, Харківської та Одеської областей, які представляють різних суб'єктів, що здійснюють заходи у сфері запобігання та протидії домашньому насильству, а саме: 27 працівників управлінь соціального захисту населення та служб у справах дітей, 32 працівника уповноважених підрозділів органів Національної поліції України, 24 працівника центрів соціальних служб для сім'ї, дітей та молоді, 15 працівників мобільних бригад соціально-психологічної допомоги постраждалим особам, 6 працівників притулків для постраждалих осіб, 6 медичних працівників та 6 працівників закладів освіти.

Законодавство зобов'язує усіх суб'єктів, що здійснюють заходи у сфері запобігання та протидії домашньому насильству:

1) відповідно до компетенції забезпечувати надання дієвої допомоги та захисту постраждалим особам;

2) ураховувати при цьому основні засади запобігання та протидії домашньому насильству.

Надаючи захист і підтримку, фахівці суб'єктів взаємодії не повинні будь-яким чином проявляти стосовно постраждалих 
зневажливе ставлення, зверхність, осуд або тиск. Може здатися, що це і так зрозуміло. Однак навіть професіонали ризикують потрапити у пастку гендерних стереотипів або почати «звинувачувати» жертву. Важливо, щоб фахівці пам'ятали про необхідність ставлення до постраждалих з повагою і чуйністю і надавали їм можливість приймати обгрунтовані рішення, які найкраще відображають їхні інтереси.

Розглянемо більш детально сучасний стан і наявні проблеми за різними напрямами надання допомоги та захисту постраждалим особам.

1. Надання постраждалим особам інформації про їхні права та можливості реалізаиії таких прав зрозумілою їм мовою або через перекладача чи залучену третю особу, яка володіє мовою, зрозумілою постраждалим особам. Для того, аби прийняти обгрунтоване, зважене рішення щодо свого життя у зв'язку із фактом домашнього насильства постраждала особа повинна мати усю необхідну для цього інформацію. Тому кожен суб’єкт повинен поінформувати постраждалу особу та/ або її законного представника про їхні права та можливості реалізації таких прав. Надання такої інформації «зрозумілою їм мовою» передбачає висловлювання в такий спосіб, що забезпечує чіткість, компактність та впорядкованість інформації (або читабельність і зрозумілість документів) з метою максимально швидкого, легкого й повного розуміння інформації та її подальшого використання. Якщо ж виникає потреба у залученні перекладача чи іншої третьої особи, то слід ретельно підходили до їх відбору. Зокрема, потрібно, щоб така особа: а) мала належний рівень володіння як мовою, якою постраждалим особам надається інформація про права та можливості реалізації таких прав (наприклад, українською), так і зрозумілою постраждалим особам мовою (наприклад, мовою жестів, ромською мовою або іншими мовами); б) не була зацікавлена у позитивних для кривдника результатах справи щодо факту домашнього насильства (наприклад, через наявність родинних зв'язків, дружніх стосунків, матеріальної заінтересованості тощо).

Усі опитані нами експерти підтвердили важливість цього напряму та зазначили, що на практиці постраждалі особи мало що запам'ятовують із того, що їм розповідають, через сильні емоції, викликані ситуацією насильства (стрес, хвилювання, страх тощо), та доволі значний обсяг отриманої інформації. Тому 76 \% опитаних заявили, що вже мають різного роду письмові матеріали (пам'ятки, візитівки, листівки), надруковані як типографським способом, так і просто на принтері, які вони роздають постраждалим у зв'язку з реагуванням на факт домашнього насильства. Також вони зазначили, що певним пробілом наразі є відсутність у таких матеріалах інформації з контактами різних суб'єктів, до яких постраждала особа може звернутись саме у її населеному пункті.

2. Забезпечення доступу до загальних та спечіалізованих служб підтримки постраждалих осіб для отримання сочіальних послуг, медичної, сочіальної, психологічноі допомоги. Нагадаємо, що до загальних служб підтримки постраждалих осіб належать заклади, які у тому числі надають допомогу постраждалим особам: центри соціальних служб для сім'ї, дітей та молоді; притулки для дітей; центри соціально-психологічної реабілітації дітей; соціально-реабілітаційні центри (дитячі містечка); центри соціальнопсихологічної допомоги; територіальні центри соціального обслуговування (надання соціальних послуг); інші заклади, установи та організації, які надають соціальні послуги постраждалим особам. До спеціалізованих служб підтримки постраждалих осіб належать притулки для постраждалих осіб, центри медико-соціальної реабілітації постраждалих осіб, кол-центр з питань запобігання та протидії домашньому насильству, насильству за ознакою статі та насильству стосовно дітей, мобільні бригади соціально-психологічної допомоги постраждалим особам та особам, які постраждали від насильства за ознакою статі, а також заклади та установи, призначені виключно для постраждалих осіб та осіб, які постраждали від насильства за ознакою статі (ч. 4 ст. 6 Закону про домашне насильство) [2].

Цей напрям передбачає, по-перше, створення таких служб підтримки у достатній кількості в межах кожного регіону / адміністративно-територіальної одиниці і, по-друге, географічно легку доступність таких служб підтримки, щоб постраждалі із сільської місцевості або постраждалі особи з інвалідністю мали такий же доступ до них, як і постраждалі з великих міст.

Міністерством соціальної політики України у співпраці та за підтримки Фонду ООН у галузі народонаселення (UNFPA) і міжнародних партнерів починаючи з 2015 року були запроваджені такі моделі сервісів: притулки для постраждалих, мобільні бригади соціально-психологічної допомоги, бригади поліцейського реагування (т.зв. «ПОЛІНА»), національна гаряча лінія. Натепер ними вже охоплюється територія 10 областей України; спеціалізовані послуги почали надаватися не тільки за рахунок міжнародних донорів, 
а й за фінансування держави і місцевих громад. Як зазначає Н. В. Федорович, в областях, які найбільше охоплені роботою мобільних бригад соціально-психологічної допомоги та інших недержавних надавачів послуг (Донецька та Луганська області), кількість звернень до соціальних служб із приводу домашнього насильства зросла більше ніж у півтора рази. У тих самих областях, згідно зі звітом ОБСЄ, зростає й усвідомлення проблеми насильства: інформацією охоплені 53 \% жінок. Схожі процеси відбуваються i в тих областях, де йде робота 3 розвитку мережі сервісів. Проте лише 24 \% учасників дослідження згадали про нещодавні кампанії проти насильства над жінками. Водночас дані дослідження свідчать: українські жінки відчувають брак доступу до спеціалізованих послуг. Лише половина із них вважає себе досить або певною мірою поінформованими про власні дії у випадку насильства. Вісім відсотків жінок України, за даними дослідження, постраждали від конфлікту. До того ж жінки, чиї нинішні партнери брали або беруть участь у бойових діях, мають значно вищий рівень імовірності потерпання від психологічного, фізичного й сексуального насильства 3 боку своїх партнерів, аніж ті, чиї партнери не брали або не беруть участі в бойових діях (79 \% і 58 \% відповідно) [3]. Майже 80 \% опитаних нами експертів також наголосили на наявності у їхньому регіоні / населеному пункті проблеми низької доступності осіб з інвалідністю та маломобільних груп населення до служб протидії домашньому насильству.

3. Надання у разі потреби тимчасового притулку для безпечного розміщення постраждалих осіб. Оскільки держава гарантує, що безпека постраждалих є першочерговим завданням, то у разі загрози життю і здоров'ю для забезпечення цієї гарантії передбачене надання такій особі тимчасового притулку. При цьому завданнями притулку для постраждалих від насильства осіб $€$ не тільки забезпечення їх місцем безпечного тимчасового цілодобового перебування, але й надання таким особам за місцем безпечного тимчасового цілодобового перебування комплексної допомоги (психологічних, соціально-побутових, соціально-медичних, інформаційних, юридичних та інших послуг) на основі оцінки їхніх потреб та індивідуального підходу до особи з урахуванням віку, статі, стану здоров'я та соціального становища [4].

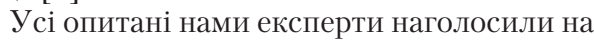
тому, що питання тимчасового притулку для безпечного розміщення постраждалих осіб у їхніх населених пунктах не можна вважати таким, що вирішене повністю. За стандартом Ради Європи на кожні 7-10 тисяч мешканців має бути створене одне сімейне місце, тобто місце для жінки з дітьми, в притулках чи інших соцустановах. Нині в Україні такі притулки лише почали створюватися. Місць там на всіх, хто їх потребує, не вистачає, на чому наголошують правозахисники. Так, приміром, на 1,7 млн населення Київської області мало би бути створено 170 місць. У $\dddot{1}$ поки що єдиному спеціалізованому притулку можуть жити одночасно 15 осіб. I навіть якщо до цього додати ще місця, які доступні в різних неспеціалізованих соціальних установах, як-от: кризові центри чи притулки для дітей, - їх усе одно замало. Спеціалізовані притулки для постраждалих жінок за допомогою міжнародних донорів створені та вже діють сьогодні, крім Київської області, в містах Києві, Харкові та Харківській області, Одесі, Бердянську, Маріуполі, Кривому Розі, Слов'янську, Херсоні та Вінницькій області [5].

4. Забезпечення постраждалим особам доступу до правосуддя та інших механізмів юридичного захисту у тому числі шляхом надання безоплатної правової допомоги y порядку, встановленому Законом України «Про безоплатну правову допомогу». У разі, якщо постраждала особа бажає притягти кривдників до відповідальності, застосувати до них спеціальні заходи щодо протидії домашньому насильству, відшкодувати завдану насильством шкоду, для неї передбачена можливість: звернутися до правоохоронних органів; звернутися до суду; отримати безоплатну правову допомогу (первинну і вторинну). За загальним правилом отримання допомоги постраждалими особами грунтується на їхньому вільному волевиявленні: саме постраждала особа визначає, чи бажає вона звертатись до правоохоронних органів і суду. Опитані нами експерти звернули увагу на зниження можливостей постраждалих осіб у доступі до правосуддя через системний некомплект у багатьох судах їх регіонів, а у деяких судах - взагалі на відсутність жодного судді.

Центри з надання безоплатної вторинної правової допомоги забезпечують надання безоплатної правової допомоги постраждалим особам у порядку, встановленому Законом України «Про безоплатну правову допомогу», за зверненням постраждалої особи або ії законного представника, в тому числі у приміщенні загальної/спеціалізованої служби підтримки постраждалих осіб, якщо постраждала особа не може відвідати центр 3 надання безоплатної вторинної правової допомоги самостійно, про що центру 
повідомляється відповідною службою. Нині затверджений перелік документів, що підтверджують належність постраждалих осіб до суб'єктів права на безоплатну вторинну правову допомогу [6]. Під час науково-практичної конференції «Відповідальність за домашне насильство і насильство за ознакою статі: новели Кримінального кодексу України», яка відбулась 12 лютого 2019 року, директор Координаційного центру з надання правової допомоги О. Бонюк зазначив, що за період із 7 січня 2018 року по 1 лютого 2019 року від осіб, які постраждали від домашнього насильства, до місцевих центрів надійшло 241 письмове звернення про надання безоплатної вторинної правової допомоги.

5. Утворення иілодобового безоплатного кол-центру з питань запобігання та протидії домашньому насильству, насильству за ознакою статі та насильству стосовно дітей для забезпечення невідкладного реагування на випадки домашнього насильства, надання консультацій щодо всіх форм домашнього насильства, визначених статтею 1 Закону України «Про запобігання та протидію домашньому насильству», абонентам анонімно або з належним дотриманням правового режиму інформації з обмеженим доступом.

Постраждалі від домашнього насильства не завжди мають можливість та рішучість звернутись безпосередньо до поліції або інших суб'єктів, які здійснюють заходи у сфері запобігання та протидії домашньому насильству. Тому для надання невідкладних експертних рекомендацій i вказівок щодо безпеки реальним і потенційним постраждалим передбачене утворення цілодобового безоплатного кол-центру [2]. До завдань, які покладаються на кол-центр, належить: забезпечення належного реагування на звернення громадян про домашнього насильства; інформування та консультування 3 питань запобігання та протидії домашньому насильству; взаємодія із суб'єктами, що здійснюють заходи у сфері запобігання та протидії домашньому насильству.

Міністерством соціальної політики України наприкінці 2018 року було затверджене Положення про Державну установу «Колцентр Міністерства соціальної політики України з питань протидії торгівлі людьми, запобігання та протидії домашньому насильству, насильству за ознакою статі та насильству стосовно дітей» [7]. У грудні 2019 року Кабінет Міністрів України постановою № 1145 поширив експериментальний проект зі створення «єдиного входу» опрацювання звернень громадян та запитів на публічну інформацію на опрацювання звернень та повідомлень про/або від осіб, які постраждали від торгівлі людьми, домашнього насильства, насильства за ознакою статі, насильства стосовно дітей, або про загрозу вчинення такого насильства [8]. Проте, оскільки там працюють фахівці у галузі психології та права широкого профілю, існуе проблема підвищення професійної підготовки консультантів цієї «гарячої лінії» щодо надання фахових консультацій саме з питань запобігання та протидії домашньому насильству та насильству за ознакою статі.

\section{Висновки}

Підсумовуючи результати нашого дослідження, підкреслимо, що останніми роками були досягнуті значні позитивні зрушення у системній протидії домашньому насильству, важливим напрямом якої визначене надання допомоги і захисту постраждалим особам. До важливих напрямів удосконалення цієї діяльності, на нашу думку, можна віднести: необхідність посилення інформаційного компонента щодо послуг, за якими постраждала особа може звернутись у своєму населеному пункті; створення належної кількості служб підтримки постраждалих осіб, особливо місць їх безпечного перебування, та забезпечення їх фізичної доступності; проведення відповідних конкурсних процедур та заповнення вакансій у судах; підвищення професійної підготовки консультантів урядової «гарячої лінії» щодо надання фахових консультацій з питань запобігання та протидії домашньому насильству та насильству за ознакою статі.

\section{Список використаних джерел:}

1. Конвенція Ради Європи про запобігання насильству стосовно жінок і домашньому насильству та боротьбу з цими явищами. URL: https:// www.coe.int/ru/web/conventions/full-list/-/ conventions/rms/090000168008482 (дата звернення: 21.05.2020).

2. Про запобігання та протидію домашньому насильству : Закон України від 7 грудня 2017 року № 2229-VIII. URL: http://zakon.rada.gov.ua/laws/ show/2229-19 (дата звернення: 21.05.2020).

3. У Відні проходить Конференція високого рівня 3 протидії насильству стосовно жінок дівчат. Офічійний сайт Міністерства соиіальної політики України, 6 травня 2019. URL: https:// www.msp.gov.ua/news/17043.html (дата звернення: 06.05.2020).

4. Про затвердження Типового положення про притулок для осіб, які постраждали від домашнього насильства та/або насильства за ознакою статі : Постанова Кабінету Міністрів України від 22.08.2018 № 655. URL: http://zakon.rada.gov.ua/ 
laws/show/655-2018-\%D0\%BF (дата звернення: 21.05.2020)

5. Безп'ятчук Ж. Домашнє насильство в Україні - злочин, а не "любов". URL: https://www.bbc com/ukrainian/features-46832511 (дата звернення: 20.05.2020).

6. Про затвердження Порядку взаємоді суб'єктів, що здійснюють заходи у сфері запобігання та протидії домашньому насильству i насильству за ознакою статі : Постанова Кабінету Міністрів України від 22.08.2018 № 658. URL http://zakon.rada.gov.ua/laws/show/658-2018\%D0\%BF (дата звернення: 20.05.2020).

7. Про утворення Державної установи «Колцентр Міністерства соціальної політики України з питань протидії торгівлі людьми, запобігання та протидії домашньому насильству, насильству за ознакою статі та насильству стосовно дітей» : Наказ Мінсоцполітики від 11.12.2018 № 1852. URL: https://zakon.rada.gov.ua/laws/show/z1458-18/ print (дата звернення: 21.05.2020).

8. Про поширення експериментального проекту із створення «єдиного входу» опрацювання звернень громадян та запитів на публічну інформацію на опрацювання звернень та повідомлень про/або від осіб, які постраждали від торгівлі людьми, домашнього насильства, насильства за ознакою статі, насильства стосовно дітей, або про загрозу вчинення такого насильства : Постанова Кабінету Міністрів України від 27.12.2019 № 1145. URL : https://zakon. rada.gov.ua/laws/show/1145-2019-\%D0\%BF (дата звернення: 21.05.2020).

Alla Blaga, Olena Kochemyrovska. Aid and protection of victims of domestic violence: current state and the major challenges of the legal regulation

The article is devoted to the analysis of the content, current situation and problems that arise during the provision of assistance and protection to victims of domestic violence. This is a separate area of activity of entities in the field of prevention and counteraction to this phenomenon. It was identified that this area includes the timely intervention and cessation of the act of violence, as well as protection of the victims by the police. Victims are also supported and provided with the necessary medical, psychological, social, legal assistance and services by health care institutions, non-governmental organizations, legal aid offices and centers, prosecutors' offices, judicial authorities (access to justice), general and specialized support services for victims (shelters, telephone hotlines etc). Emphasis is placed on the need for specialists to respect and be sensitive to victims and to provide them with the opportunity to make informed decisions that best reflect their interests. The specifics of providing victims with information about their rights and opportunities to exercise such rights are analyzed and the existing shortage of printed information materials with the contacts of services to which a person can apply in their locality is indicated. Problematic issues have been identified to ensure access to general and specialized support services for victims to receive social aid, medical, social and psychological assistance. The current state and prospects of providing such persons with temporary shelter for safe accommodation have been established and the need to expand the network of specialized crisis centers has been emphasized. The situation with providing victims with access to justice and other mechanisms of legal protection, including by providing free legal aid, is analyzed. The activity of the Ministry of Social Policy of Ukraine and the Government of the country regarding the establishment of a round-the-clock free call center on prevention and counteraction to domestic violence, gender-based violence and violence against children is considered.

Key words: domestic violence, victim, prevention, protection, support. 